Versluijs, M., S. Eggers, G. Mikusiński, J.-M. Roberge, and J. Hjältén. 2020. Foraging behavior of the Eurasian Three-toed Woodpecker (Picoides tridactylus) and its implications for ecological restoration and sustainable boreal forest management. Avian Conservation and Ecology 15(1):6. https:// doi.org/10.5751/ACE-01477-150106

Copyright (C) 2020 by the author(s). Published here under license by the Resilience Alliance.

\title{
Foraging behavior of the Eurasian Three-toed Woodpecker (Picoides tridactylus) and its implications for ecological restoration and sustainable boreal forest management
}

\author{
Martijn Versluijs ${ }^{1}$, Sönke Eggers ${ }^{2}$, Grzegorz Mikusiński ${ }^{3,4}$, Jean-Michel Roberge ${ }^{1,5}$ and Joakim Hjältén ${ }^{1}$ \\ ${ }^{1}$ Department of Wildlife, Fish, and Environmental Studies, Swedish University of Agricultural Sciences (SLU), Umeå, Sweden, \\ ${ }^{2}$ Department of Ecology, Swedish University of Agricultural Sciences (SLU), Uppsala, Sweden, ${ }^{3}$ Grimsö Wildlife Research Station, \\ Department of Ecology, Swedish University of Agricultural Sciences, Riddarhyttan, Sweden, ${ }^{4}$ School for Forest Management, \\ Swedish University of Agricultural Sciences, Skinnskatteberg, Sweden, ${ }^{5}$ Swedish Forest Agency, Umeå, Sweden
}

\begin{abstract}
Several studies have shown that the Three-toed Woodpecker (Picoides tridactylus) is strongly favored by large-scale disturbances, including forest fires. However, natural disturbances have largely disappeared from European boreal forests because of modern forestry practices and fire suppression. We currently lack knowledge on the foraging activity and resource use of the Eurasian Three-toed Woodpecker, especially in burned forests, and this restricts our ability to develop strategies for sustainable forest management and ecological restoration aiming at improving the situation of this woodpecker and associated species. In order to fill this knowledge gap, we studied the characteristics of selected foraging substrates and the foraging behavior of the Three-toed Woodpecker during the breeding season in unburned forests and forests that have been subjected to prescribed burning. We used instantaneous sampling during two consecutive springs (2016-2017), where we observed the woodpeckers' foraging behavior during a total of 977 minutes in burned forest and 962 minutes in unburned forests. The preferred foraging substrate for Three-toed Woodpeckers in both burned and unburned forests can be characterized as freshly dead trees with a DBH $>15 \mathrm{~cm}$. However, data on time spent foraging on different substrates suggest that also substrates in the 5-15 DBH range and living trees are important. Additionally, prescribed burnings led to less pronounced selection of tree species, which suggest that fire may reduce differences in abundance of saproxylic insect prey between tree species. This information on substrate selection and foraging time provide complementary knowledge and thus should be used simultaneously when management strategies for improved woodpecker habitat are developed. Our results suggest that both prescribed burning and protecting forests with high density and diversity of dead wood provides habitat opportunities for Three-toed Woodpeckers and using both in management may maximize conservation outcome.
\end{abstract}

\section{Comportement d'alimentation du Pic tridactyle (Picoides tridactylus) et ses implications pour la restauration écologique et les pratiques durables d'aménagement de la forêt boréale}

RÉSUMÉ. Plusieurs études ont montré que le Pic tridactyle (Picoides tridactylus) profite des perturbations survenant sur de vastes étendues, dont les incendies de forêt. Toutefois, les perturbations naturelles n'existent presque plus dans les forêts boréales d'Europe en raison des pratiques forestières modernes et de la suppression des incendies de forêt. Le manque actuel de connaissances sur l'alimentation et l'utilisation des ressources par le Pic tridactyle, spécialement dans les forêts brûlées, restreint notre habilité à élaborer des stratégies d'aménagement durable des forêts et de restauration écologique visant à améliorer la situation de ce pic et d'autres espèces associées. Pour combler cette lacune, nous avons étudié les caractéristiques des substrats choisis pour l'alimentation et le comportement d'alimentation du Pic tridactyle durant la saison de nidification, dans des forêts non brûlées et des forêts ayant fait l'objet de brûlage dirigé. Nous avons échantillonné de façon instantanée durant deux printemps consécutifs (2016-2017), au cours desquels nous avons observé les pics s'alimenter durant 977 minutes en forêts brûlées et 962 minutes en forêts non brûlées. Le substrat favori des Pics tridactyles pour l'alimentation, tant en forêts brûlées que non brûlées, s'est révélé être des arbres fraîchement morts ayant un DHP > $15 \mathrm{~cm}$. Cependant, selon le temps dédié par les pics pour s'alimenter sur les différents substrats, ceux compris dans la fourchette de DHP située entre 5 et 15, tout comme les arbres vivants, avaient aussi leur importance. De plus, dans le cas des feux dirigés, les pics ont été moins sélectifs dans leurs essences d'arbres, laissant croire que le feu pourrait réduire la variabilité de l'abondance des insectes saproxyliques qu'ils consomment entre les essences d'arbres. Ces résultats sur la sélection de substrats et le temps dédié à l'alimentation fournissent des connaissances complémentaires et devraient être considérés simultanément au moment d'élaborer des stratégies d'aménagement visant à améliorer l'habitat de ce pic. Nos résultats indiquent que le brûlage dirigé et la protection de forêts montrant une densité et une diversité élevées de bois mort fournissent de l'habitat pour les Pics tridactyles; l'utilisation de ces deux stratégies d'aménagement pourrait maximiser les retombées de conservation.

Key Words: conservation; ecological restoration; prescribed burning; substrate selection; substrate use 


\section{INTRODUCTION}

As a consequence of human-induced habitat loss, fragmentation, and structural homogenization, many woodpecker species are threatened or have declining populations (Mikusiński 2006, Lammertink 2014, Vergara-Tabares et al. 2018). This especially concerns habitat specialists with strong affinity for old-growth forest or forest subjected to natural disturbances, e.g. windthrow, fire, and insect outbreaks. The occurrence and population dynamics of woodpeckers are strongly correlated with local habitat composition (Bütler et al. 2004a, Pechacek and d'OleireOltmanns 2004, Roberge et al. 2008, Tremblay et al. 2009, Czeszczewik et al. 2013, Kajtoch et al. 2013, Kumar et al. 2014, Ojeda and Chazarreta 2014). At the local habitat level, woodpeckers need certain structures for foraging and breeding, such as large old trees and deadwood (Walters et al. 2002, Bütler et al. 2004a, Roberge et al. 2008).

The boreal biome is a dynamical system where wildfires belong to the most important natural disturbances shaping complex forest environments (Hunter 1993, Esseen et al. 1997, Angelstam 1998, Kuuluvainen 2002, Bergeron et al. 2004, Gauthier et al. 2015) and fundamentally affecting forest biodiversity (Lowe et al. 2012, Hekkala et al. 2014, Hjältén et al. 2017, Gustafsson et al. 2019). However, because of modern forestry practices and fire suppression, natural disturbances have largely disappeared from the European boreal forest and have been replaced by anthropogenic disturbances, including thinning, clearcutting, soil scarification, and planting of conifers (Esseen et al. 1997, Östlund et al. 1997, Linder and Östlund 1998, Wallenius 2011, Rolstad et al. 2017). Prescribed burning, as a form of ecological restoration, is assumed to be an efficient way to emulate wildfire and to create habitats for a range of different species including woodpeckers (Hjältén et al. 2017, Versluijs et al. 2017).

The Eurasian Three-toed Woodpecker (Picoides tridactylus), included in annex I of the EU Birds Directive and red-listed as "near threatened" in Sweden, is generally classified as an oldgrowth forest specialist (Pakkala et al. 2002, Pechacek and d'Oleire-Oltmanns 2004, Wesołowski et al. 2005, StachuraSkierczyńska et al. 2009). However, several studies have shown that Three-toed Woodpeckers (including the American Threetoed Woodpecker Picoides dorsalis) are strongly favored by largescale disturbances causing elevated mortality of trees, including forest fires (Murphy and Lehnhausen 1998, Hoyt and Hannon 2002, Fayt 2003, Nappi and Drapeau 2009, Edworthy et al. 2011, Versluijs et al. 2017). Fire induces profound changes in stand characteristics, which influence tree substrate availability and quality (Stokland et al. 2012, Hjältén et al. 2017, 2018). This may result in changes in both the abundance and assemblage composition of saproxylic insects, the main food source of Threetoed Woodpeckers (Saint-Germain et al. 2004a, b, 2008, Hyvärinen et al. 2009, Boucher et al. 2012, Hekkala et al. 2014, Kärvemo et al. 2017). It has been suggested that burning homogenizes the quality of tree species in terms of nutrients and structure, making them more equal for saproxylic insects and reduces differences in insect diversity among tree species (Wikars 2002, Toivanen and Kotiaho 2010). This, in turn, could result in woodpeckers being less likely to discriminate between tree species when foraging in burned forest.
Observational studies of Three-toed Woodpeckers in unburned forest in Norway and central Europe suggest that they spend most of their foraging time on dead standing, large diameter Norway spruces (Picea abies; $>10 \mathrm{~cm}$ ) in an early decay stage (Hogstad $1977,1991)$. The woodpecker's primary foraging method is barkscaling on the trunk (Hogstad 1977, 1991, Pechacek 2006a). Similar foraging strategies have been reported in the American Three-toed Woodpecker, a species closely related to the Eurasian Three-toed Woodpecker. The American Three-toed Woodpecker tends to use larger diameter, recently dead (standing) conifer trees but living trees are important as well for sap licking (Imbeau and Desrochers 2002, Nappi et al. 2015). The use of recently dead conifer trees by the woodpecker may be explained by its specialization on bark beetles as a main prey. Nappi et al. (2015) found that trees used for foraging contained high abundance of Scolytinae beetles. In burned forests, the American Three-toed Woodpecker exhibits similar foraging preferences as in unburned forests (Murphy and Lehnhausen 1998). However, our knowledge on the foraging activity and resource use of Eurasian Three-toed Woodpecker is more limited, especially in burned forest. Understanding the foraging ecology of woodpeckers and their associations to tree characteristics is necessary for successful conservation work in managed forest landscapes. Thus, the lack of this knowledge restricts our ability to develop strategies for sustainable forest management and ecological restoration aiming at improving the situation of this woodpecker and associated species. This is particularly important in light of an expected increase in the frequency of wildfires in Northern Europe (Lehtonen et al. 2016), requiring development of efficient postfire management strategies that are in line with biodiversity conservation objectives. In this context, the Three-toed Woodpecker can be seen as a model species for biodiversity conservation, management, and ecological restoration in boreal and high-altitude forests. This is due to its sensitivity to habitat changes, potential importance as an indicator species for biodiversity (Mikusiński et al. 2001, Roberge and Angelstam 2006, Drever et al. 2008, Versluijs et al. 2019), and keystone role in providing cavities for secondary cavity-nesters (Pakkala et al. $2018 a$ ), a process of particular importance in boreal forests where decay-formed tree cavities are very rare (Andersson et al. 2018).

The objective of this study is to improve our understanding of the foraging ecology of Three-toed Woodpeckers and associated tree dynamics, necessary to develop strategies for sustainable forest management and ecological restoration. Therefore, the foraging substrate preferences of the Eurasian Three-toed Woodpecker was determined during the breeding season in unburned forests and forests that have been subjected to prescribed burning (5-6 years after treatment). We achieved this by studying (i) the selection of individual foraging substrates by the woodpecker and (ii) the allocation of foraging time among substrates with different characteristics. We expected tree species, decay stage, and tree diameter to be important characteristics determining the selection of foraging substrates. Furthermore, we predicted a difference in foraging behavior as measured through foraging time (regarding the use of different tree species, decay stages, tree diameter, and position on the substrates) between burned and unburned forest as substrate properties change because of fire. 


\section{METHOD}

\section{Study area}

The study area is located in the middle and northern boreal zones (Ahti et al. 1968) of northern Sweden $\left(63^{\circ} 23^{\prime} \mathrm{N}\right.$ to $65^{\circ} 02^{\prime} \mathrm{N}$ and $16^{\circ} 80^{\prime} \mathrm{E}$ to $\left.21^{\circ} 20^{\prime} \mathrm{E}\right)$. Data was collected in 30 forest stands of varying sizes, ranging from 3.5 to 25 hectares. The distance between neighboring study stands was $\geq 1 \mathrm{~km}$. All stands were selected to be as similar as possible in terms of tree species composition and forest age. All stands were conifer-dominated, with a mixture of Scots pine (Pinus sylvestris) and Norway spruce and at least $10 \%$ deciduous trees. The most common deciduous tree species were silver birch (Betula pendula), downy birch (Betula pubescens), European aspen (Populus tremula), and goat willow (Salix caprea). Twenty stands were initially normal production stands, which were converted into voluntary set-asides and protected as part of Forest Stewardship Council (FSC) certification. All study stands were mature forest stands $(>80$ years) that have never been clear-felled but historically subjected to selective felling. In 10 of the stands, prescribed burning was conducted in 2011. Before burning, 5-30\% of the trees were harvested to improve local conditions for burning (by speeding up the drying out of the ground vegetation) and to cover the costs associated with the burning treatment. In addition to the extracted timber, approximately $2-5 \mathrm{~m}^{3} / \mathrm{ha}$ of the cut trees were left on the ground as fuel. Fire intensity (measured as the ratio between living and dead coniferous trees after fire) ranged from 0.23 to 1.00 in the prescribed burning stands. The remaining stands (10 voluntary set-asides and 10 stands located in formally protected nature reserves) are referred to as unburned forest stands. More detailed stand information regarding basal area and DBH of living and standing dead wood can be found in Table 1 .

\section{Focal observations}

Fieldwork was carried out from the beginning of April to the end of June in 2016 and 2017. We located Three-toed Woodpecker individuals by walking slowly through the study stands, using both auditory (drumming and pecking sounds of foraging woodpeckers) and visual cues to detect the birds. Our study stands were smaller than the average territory size of the woodpecker (typically 60-340 ha; Pakkala et al. 2002, Pechacek 2004, Pechacek and d'Oleire-Oltmanns 2004). Studies of spacing behavior done in Germany demonstrated that the area used over the breeding season remain stable and home ranges of pairs (male and female) overlap with 66\% (Pechacek 2004). Because it was not possible to distinguish individuals (the woodpeckers were not marked), repeated observation of a bird of a given sex in a given year in a study stand were treated as dependent units in the analyses. Pechacek (2006b) showed that although Three-toed Woodpeckers have a high breeding site fidelity between years, $60 \%$ of the observed woodpeckers found a new mate due to death or divorce. Because of this, we treated observations in the same stands but from two different years as independent observations.

Once a bird was found, it was observed until it flew out of sight. We kept an observation distance of $>10 \mathrm{~m}$ from the bird to avoid disturbances. We used instantaneous sampling, i.e., fixed interval time point (Martin and Bateson (1993), where we recorded for every minute if the individual was foraging or not. When the woodpecker was foraging, we recorded the following variables: foraging height, foraging site (trunk, branch, or exposed roots), and substrate diameter at foraging height (estimate at nearest $\mathrm{cm}$ using the Three-toed Woodpecker's body length [20-24 cm] as a reference). We recorded foraging height in four classes; $1(0-2 \mathrm{~m})$, $2(2-5 \mathrm{~m}), 3(5-10 \mathrm{~m})$, and $4(>10 \mathrm{~m})$. We distinguished three foraging techniques (Villard 1994, Murphy and Lehnhausen 1998, Imbeau and Desrochers 2002): (1) bark scaling accompanied by surface pecking, (2) excavation into sapwood, and (3) sap-licking. For each substrate selected by a Three-toed Woodpecker we recorded tree species (pine, spruce, birch, aspen, and other deciduous trees); DBH in $10 \mathrm{~cm}$ classes: (i) 5-15, (ii) $15-25$, (iii) 25-35, (iv) 35-45; tree health status/decay stages (hereafter "decay stage" for conciseness) based on four classes (Thomas et al. 1979): (1) healthy living tree, (2) dying tree that is still alive, (3) recently dead tree with $100 \%$ bark attached, (4) dead tree with $<100 \%$ bark attached. To determine the availability of substrates in the immediate vicinity of the selected trees, we also recorded data for all of the variables pertaining to substrate characteristics for the nearest available tree with a $\mathrm{DBH}>5 \mathrm{~cm}$.

\section{Statistical analysis}

\section{Characteristics of selected foraging substrates}

As a first step, we evaluated which of the different substrate variables most likely determined the potential of a tree to be used as foraging substrate. This was done by using each utilized substrate as the basic unit of observation, without accounting for the total observation time per individual substrate. We attributed a unique identification number with information about tree species, DBH, and decay stage to each individual tree used for foraging by Three-toed Woodpecker. We used conditional logistic regression with the clogit function from the "survival" package in R (Therneau and Lumley 2009) to analyze selection for different foraging substrates as a function of their characteristics. Conditional logistic regression is a type of logistic regression model based on matched case-control pairs. Here, we matched each used tree with the nearest available tree, hence allowing to control for local habitat differences regarding substrate availability. The total number of trees selected differed between woodpecker individuals. To account for these differences, we statistically weighted the number of trees used by an individual. For example, individual selection preference based on 100 used trees counted twice as much as one based on only 50 trees. Consequently, each woodpecker individual contributed only 1 degree of freedom in the model regardless of its number of observations (Desrochers 1992). This approach allowed us to use all observations while avoiding pseudo-replication (Machlis et al. 1985). We ran the models with tree species, DBH, and decay stage as independent variables and separately for burned and unburned forests, using backward elimination to select the best model.

Additionally, we used Manly selection ratios (Manly et al. 2002) for each substrate characteristic found to be the best predictor according to the conditional logistic regression models. Selection ratios are based on the ratio between substrate used by Threetoed Woodpecker and its availability, i.e., the nearest tree available tree. The substrate type is considered "preferred" when the $95 \%$ confidence interval (CI) of its selection ratio is $>1$, as "avoided" when the $95 \% \mathrm{CI}$ is $<1$, and as used proportionally to its availability when the $95 \%$ CI includes 1 (Manly et al. 2002). 
Table 1. Habitat structure of burned and unburned forest. Basal area and mean diameter at breast height $(\mathrm{DBH} ; \pm \mathrm{SE})$ are provided separately for four tree health statuses / decay stages and three tree species. Tree health status / decay stage is based on four classes: (1) healthy living tree, (2) dying tree that is still alive, (3) recently dead tree with $100 \%$ bark attached, (4) dead tree with $<100 \%$ bark attached.

\begin{tabular}{|c|c|c|c|c|c|}
\hline \multirow[b]{2}{*}{ Tree species } & \multirow[b]{2}{*}{$\begin{array}{c}\text { Tree health status / decay } \\
\text { stage }\end{array}$} & \multicolumn{2}{|c|}{ Burned forest } & \multicolumn{2}{|c|}{ Unburned forest } \\
\hline & & $\begin{array}{c}\text { Basal area } \\
\left(\mathrm{m}^{2} \mathrm{ha}^{-1}\right)\end{array}$ & $\mathrm{DBH}(\mathrm{cm})$ & $\begin{array}{c}\text { Basal area } \\
\left(\mathrm{m}^{2} \mathrm{ha}^{-1}\right)\end{array}$ & $\mathrm{DBH}(\mathrm{cm})$ \\
\hline Scots pine & $\begin{array}{l}1 \\
2 \\
3 \\
4\end{array}$ & $\begin{array}{c}8.7 \pm 1.7 \\
0.1 \pm 0.05 \\
1.6 \pm 0.3 \\
1.3 \pm 0.3\end{array}$ & $\begin{array}{l}23.9 \pm 0.4 \\
15.1 \pm 2.5 \\
17.8 \pm 0.3 \\
22.5 \pm 0.4\end{array}$ & $\begin{array}{c}10.4 \pm 1.8 \\
0.03 \pm 0.01 \\
0.1 \pm 0.03 \\
0.5 \pm 0.1\end{array}$ & $\begin{array}{l}26.1 \pm 0.4 \\
14.5 \pm 4.2 \\
13.7 \pm 0.5 \\
21.9 \pm 0.4\end{array}$ \\
\hline Norway spruce & $\begin{array}{l}1 \\
2 \\
3 \\
4\end{array}$ & $\begin{array}{c}1.6 \pm 0.5 \\
- \\
3.2 \pm 0.5 \\
0.2 \pm 0.05\end{array}$ & $\begin{array}{c}15.3 \pm 0.5 \\
- \\
13.6 \pm 0.1 \\
14.8 \pm 0.4\end{array}$ & $\begin{array}{c}15.1 \pm 1.1 \\
0.04 \pm 0.03 \\
0.5 \pm 0.1 \\
0.1 \pm 0.04\end{array}$ & $\begin{array}{l}15.3 \pm 0.1 \\
18.5 \pm 4.9 \\
15.1 \pm 0.2 \\
16.2 \pm 0.4\end{array}$ \\
\hline Birch & $\begin{array}{l}1 \\
2 \\
3 \\
4\end{array}$ & $\begin{array}{c}0.9 \pm 0.3 \\
0.02 \pm<0.01 \\
1.7 \pm 0.3 \\
0.1 \pm 0.05\end{array}$ & $\begin{array}{l}17.6 \pm 0.4 \\
16.5 \pm 1.8 \\
12.5 \pm 0.1 \\
13.5 \pm 0.5\end{array}$ & $\begin{array}{c}2.5 \pm 0.3 \\
0.05 \pm 0.02 \\
0.3 \pm 0.05 \\
-\end{array}$ & $\begin{array}{c}14.2 \pm 0.1 \\
14.2 \pm 0.7 \\
13.0 \pm 0.2 \\
-\end{array}$ \\
\hline
\end{tabular}

Foraging behavior as measured through foraging time To determine how substrate characteristics influenced foraging time, we analyzed time spent foraging on a specific substrate (number of foraging minutes per observation session) in relation to substrate characteristics. We analyzed time spent foraging with tree species, $\mathrm{DBH}$, and decay stages in interaction with forest type, i.e., unburned or burned forest, as factors using a generalized linear mixed model (GLMM) with Poisson distribution. We included the bird's sex in the model whenever significant to control for intersexual differences in foraging behavior. We included forest stand and year as random variables, and the logarithm of total observation time per session as an offset. Furthermore, the foraging position on the tree regarding foraging height and diameter of foraging substrate was modeled. Foraging height was collected as categorical data; therefore we used the same model structure as in the previous analysis. A linear mixed model (LMM) was used to determine the importance of substrate diameter at foraging height. In all models we used backward elimination to select the best model. All foraging sessions longer than 5 min were included in the analyses pertaining to foraging time. For graphical representation, we plotted the predicted model outcomes.

\section{RESULTS}

In 2016, we collected 638 minutes of observations from 14 different woodpecker individuals (Table 2). In total, we observed six individuals (three males and three females) in burned stands and eight individuals (four males and four females) in unburned stands. In 2017, we collected 1301 minutes of observations from 12 different individuals. We observed six of these individuals in burned stands (three males and three females) and six individuals (three males and three females) in unburned stands. In total, 203 utilized trees in burned forest and 94 utilized trees in unburned forest formed the basis for assessing foraging substrate selection and foraging time spent by woodpeckers (Table 2).

\section{Characteristics of selected foraging substrates}

Tree species $(\mathrm{p}<0.001)$, decay stage (burned: $\mathrm{X}_{\text {Decay stage }}^{2}=11.3$, $\mathrm{p}<0.001$, unburned: $\left.\mathrm{X}_{\text {Decay stage }}^{2}=16.7, \mathrm{p}<0.001\right)$ and $\mathrm{DBH}$ (burned: $\mathrm{X}_{\mathrm{DBH}}^{2}=17.4, \mathrm{p}<0.001$, unburned: $\mathrm{X}_{\mathrm{DBH}}^{2}=15.1, \mathrm{p}<$ $0.001)$ predicted characteristics of foraging substrate in both burned and unburned forest stands (Table 3). In burned stands, Three-toed Woodpeckers were less likely to be found foraging on pine than on spruce and birch. Even though pine was avoided in burned forest, birch and spruce were not used more than proportionally to their availability (Fig. 1A). Hence, none of the latter two species was significantly preferred. Decay stage influenced substrate selection: healthy living trees (decay stage 1) were avoided and recently dead trees (decay stage 3 ) were preferred (Fig. 1B). Additionally, trees in the category of DBH $15-25 \mathrm{~cm}$ and $35-45 \mathrm{~cm}$ were preferred whereas trees with a DBH in the category of 5-15 were avoided (Fig. 1C).

In unburned stands, spruce was significantly preferred over birch and pine, additionally birch was preferred over pine (Table 3 ). This was supported by the selection ratios, which showed that spruce was preferred and pine was avoided (Fig. 1A). Three-toed Woodpeckers preferred dying trees (decay stage 2), recently dead trees (decay stage 3), and trees dead for a longer time (decay stage 4). They also preferred trees with a DBH of 15-25 cm (Fig. 1B and $\mathrm{C}$ ). Trees with $\mathrm{DBH}$ in the category of 5-15 and living trees were avoided (Fig. 1B and C).

\section{Foraging behavior as measured through foraging time}

Bark scaling was the most common foraging method, accounting for $85.3 \%$ of the foraging time in burned forest and $80.1 \%$ in unburned forest. The second most common foraging method was sap licking, with $14.7 \%$ of the foraging time in burned forest and $19.9 \%$ in unburned forest. Three-toed Woodpecker prefer larger DBH trees for sap licking; all observations were collected on trees 
Table 2. Total observation time (minutes), total foraging time (minutes), number of used trees, and mean sampling intervals $( \pm$ SE) divided between sex and given over the two study years. $n=$ number of woodpecker individuals.

\begin{tabular}{|c|c|c|c|c|c|c|c|c|c|c|c|}
\hline \multirow[b]{2}{*}{ Year } & \multirow[b]{2}{*}{ Sex } & \multicolumn{5}{|c|}{ Burned forest } & \multicolumn{5}{|c|}{ Unburned forest } \\
\hline & & $\mathrm{n}$ & $\begin{array}{c}\text { Observation } \\
\text { time }\end{array}$ & $\begin{array}{c}\text { Foraging } \\
\text { time }\end{array}$ & $\begin{array}{l}\text { Used } \\
\text { trees }\end{array}$ & $\begin{array}{c}\text { Sampling } \\
\text { intervals } \\
(\text { mean } \pm \mathrm{SE})\end{array}$ & $\mathrm{n}$ & $\begin{array}{c}\text { Observation } \\
\text { time }\end{array}$ & $\begin{array}{l}\text { Foraging } \\
\text { time }\end{array}$ & $\begin{array}{l}\text { Used } \\
\text { trees }\end{array}$ & $\begin{array}{c}\text { Sampling } \\
\text { intervals } \\
\text { (mean } \pm \mathrm{SE})\end{array}$ \\
\hline 2016 & $\mathrm{M}$ & 3 & 162 & 151 & 73 & $27.3 \pm 4.9$ & 4 & 93 & 82 & 17 & $17.6 \pm 4.5$ \\
\hline 2016 & $\mathrm{~F}$ & 3 & 221 & 176 & 51 & $24.2 \pm 4.1$ & 4 & 162 & 129 & 16 & $29.2 \pm 11.0$ \\
\hline 2017 & M & 3 & 273 & 95 & 47 & $53.2 \pm 21.2$ & 3 & 443 & 204 & 39 & $44.0 \pm 9.0$ \\
\hline 2017 & $\mathrm{~F}$ & 3 & 321 & 134 & 32 & $26.0 \pm 4.2$ & 3 & 264 & 185 & 22 & $23.3 \pm 4.1$ \\
\hline
\end{tabular}

Table 3. Parameter estimates and odds ratios for conditional logistic regression models describing characteristics of trees used by foraging Three-toed Woodpeckers (Picoides tridactylus) in burned and unburned forest. Models were run separately for the two forest types. Sex was excluded because it was not significant in the models. DBH, diameter at breast height.

\begin{tabular}{|c|c|c|c|c|c|}
\hline $\begin{array}{l}\text { Model } \\
\qquad \text { Parameter }\end{array}$ & $\begin{array}{l}\text { Esti- } \\
\text { mate }\end{array}$ & SE & $\mathrm{T}$ & $\mathrm{P}$ & $\begin{array}{l}\text { Odds ratio } \\
(95 \% \mathrm{CI})\end{array}$ \\
\hline \multicolumn{6}{|l|}{ A. Burned forest } \\
\hline $\begin{array}{l}\text { Tree species (birch } \\
\text { vs. spruce) }\end{array}$ & 0.07 & 0.09 & -0.79 & 0.430 & $1.07(0.89-1.28)$ \\
\hline $\begin{array}{l}\text { Tree species (pine } \\
\text { vs. spruce) }\end{array}$ & -1.11 & 0.09 & -12.01 & $<0.001$ & $0.32(0.27-0.39)$ \\
\hline $\begin{array}{l}\text { Tree species (pine } \\
\text { vs. birch) }\end{array}$ & -1.18 & 0.11 & -10.12 & $<0.001$ & $0.30(0.24-0.38)$ \\
\hline Decay stage & 0.45 & 0.04 & 11.34 & $<0.001$ & $1.63(1.49-1.77)$ \\
\hline $\mathrm{DBH}$ & 0.08 & 0.01 & 17.35 & $<0.001$ & $1.08(1.07-1.09)$ \\
\hline \multicolumn{6}{|l|}{ B. Unburned forest } \\
\hline $\begin{array}{l}\text { Tree species (birch } \\
\text { vs. spruce) }\end{array}$ & -1.14 & 0.20 & -5.58 & $<0.001$ & $0.32(0.21-0.48)$ \\
\hline $\begin{array}{l}\text { Tree species (pine } \\
\text { vs. spruce) }\end{array}$ & -3.73 & 0.25 & -14.56 & $<0.001$ & $0.02(0.01-0.04)$ \\
\hline $\begin{array}{l}\text { Tree species (pine } \\
\text { vs. birch) }\end{array}$ & -2.59 & 0.27 & -9.57 & $<0.001$ & $0.07(0.04-0.12)$ \\
\hline Decay stage & 1.13 & 0.06 & 16.67 & $<0.001$ & $3.09(2.71-3.53)$ \\
\hline DBH & 0.13 & 0.01 & 15.1 & $<0.001$ & $1.15(1.13-1.17)$ \\
\hline
\end{tabular}

with a DHB larger than $15 \mathrm{~cm}$, with $54 \%$ on trees with a DBH between $15-25 \mathrm{~cm}$. Excavation into sapwood was neither observed in burned forest nor in unburned forest. In both forest types, the trunk was the most common foraging location, representing $96.8 \%$ of the foraging time in burned forest and $95.8 \%$ in unburned forest. We did not recorded any observation of Three-toed Woodpeckers using lying dead trees as a foraging substrate, in spite of the presence of substantial amounts of it in some of the study stands. The average foraging time per used tree did not differ between burned and unburned forest $\left(X^{2}=1.6, d f=1, p=0.209\right)$.

Substrate diameter at foraging height did not differ between burned and unburned forest $\left(\mathrm{X}^{2}=0.03\right.$, $\left.\mathrm{df}=1, \mathrm{p}=0.854\right)$ or between sexes $\left(\mathrm{X}^{2}=1.76, \mathrm{df}=1, \mathrm{p}=0.183\right)$ and was on average $18.2 \mathrm{~cm}$ in burned forest and $17.1 \mathrm{~cm}$ in unburned forest. Males spent significantly more time foraging on the lower part $(<2 \mathrm{~m})$ of trees compared to females $\left(\mathrm{X}^{2}=115.6, \mathrm{df}=3, \mathrm{p}<0.001\right.$, Fig. 2A). Moreover, independent of sex, Three-toed Woodpeckers in burned areas spent significantly more time foraging below $2 \mathrm{~m}$ than at higher heights $\left(\mathrm{X}^{2}=83.5, \mathrm{df}=4, \mathrm{p}<0.001\right.$, Fig. $\left.2 \mathrm{~B}\right)$. In
Fig. 1. Manly selection ratios with $95 \%$ confidence intervals for tree species, decay stage, and diameter at breast height (dbh). Selection ratios are based on the ratio between substrate selected by Three-toed Woodpeckers (Picoides tridactylus) and availability (measured as the nearest tree). Values above 1 (horizontal line) indicate preference, and values below 1 indicate avoidance.
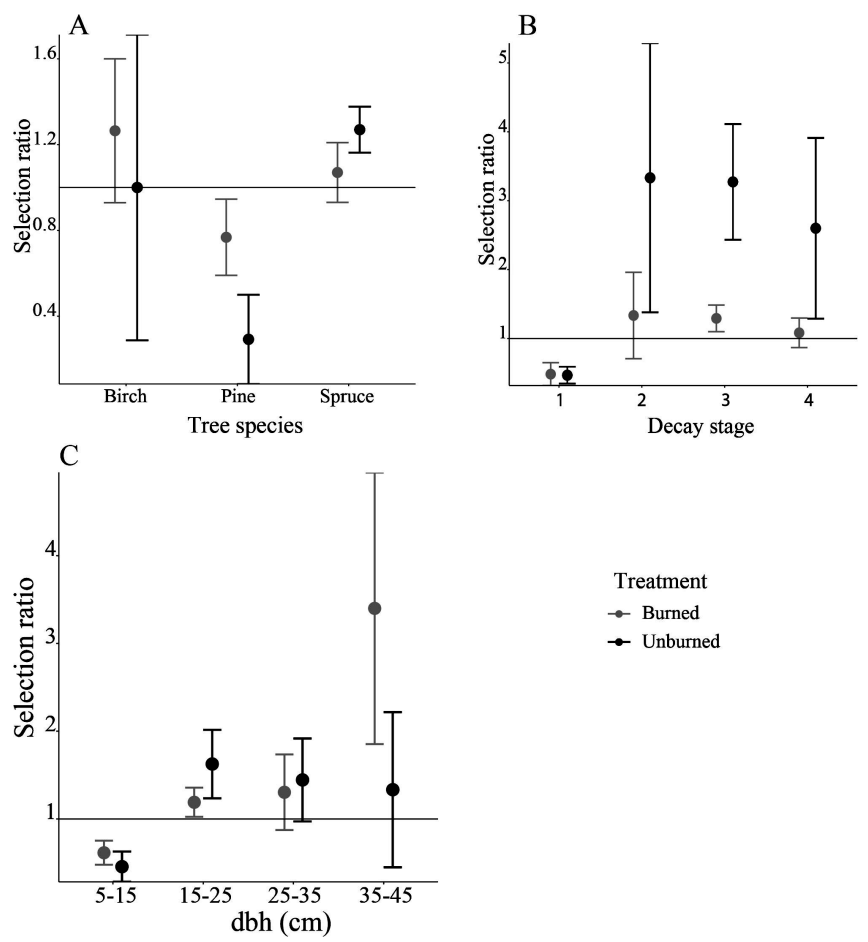

Treatment

$\rightarrow$ Burned

$\rightarrow$ Unburned

contrast, Three-toed Woodpeckers in unburned forests foraged less often below $2 \mathrm{~m}$ than at higher heights.

The distribution of the observed foraging time among different tree species, trees belonging to different decay stages, and DBH were influenced by forest type (tree species: $\mathrm{X}^{2}=25.2$, df $=2, \mathrm{p}$ $<0.001$; decay stage: $\mathrm{X}^{2}=26.5$, df $=3, \mathrm{p}<0.001$; DBH: $\mathrm{X}^{2}=$ $46.1, \mathrm{df}=3, \mathrm{p}<0.001)$. In burned forest, Three-toed Woodpeckers spend slightly more foraging time on birch and spruce compared to pine (Fig. 3A). In unburned forest, differences in foraging time among tree species were larger than in burned forest: Three-toed Woodpeckers spend most of their foraging time on spruce and 
Fig. 2. Predicted mean foraging time (minutes) per observation session with standard error (SE) of foraging height in relation to (A) sex, (B) treatment. Results derived from GLMM models with Poisson distribution. Forest stand and year were included as random variables.
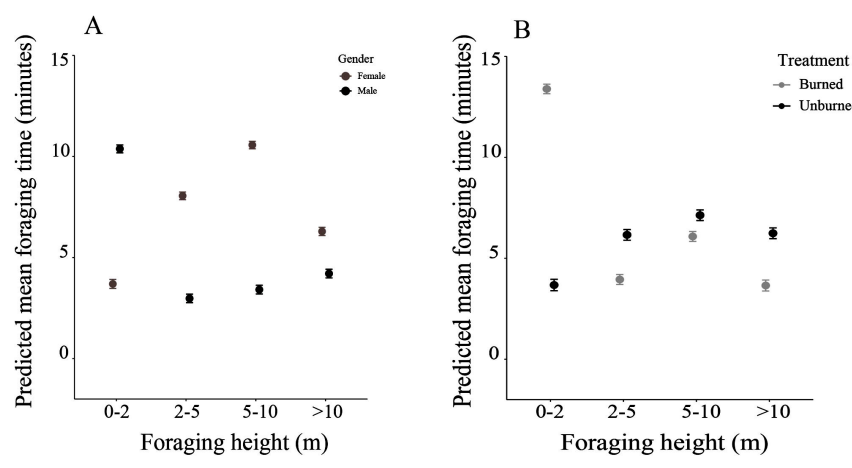

Fig. 3. Predicted mean foraging time (minutes) per observation session with standard error (SE) for substrates belonging to different (A) tree species, (B) decay stages, and (C) diameter at breast height ( $\mathrm{dbh}$ ) classes. Results derived from GLMM models with Poisson distribution and corrected for differences between sex, forest stand, and year were included as random variables.
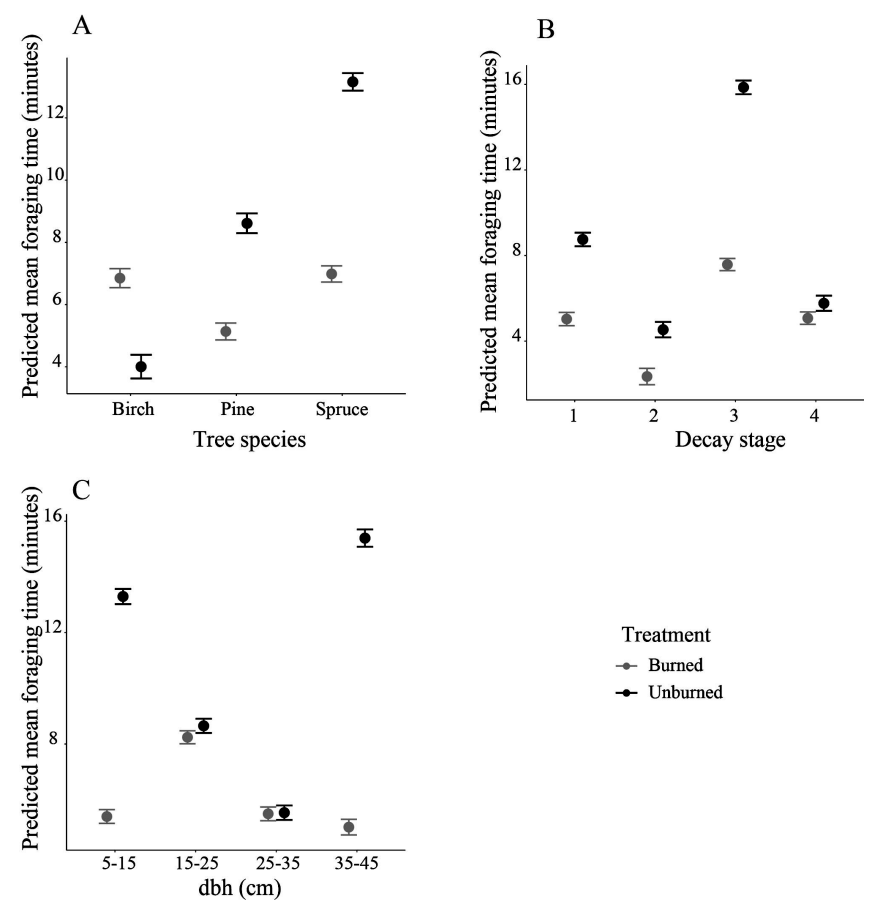

least time on birch (Fig. 3A). In both forest types, decay stage 3 had the highest mean predicted foraging time (Fig. 3B). Furthermore, a considerable amount of foraging time was spent on healthy living trees (decay stage 1). In burned forest, Threetoed Woodpeckers, spent the most time foraging on trees with a
DBH between 15-25 cm. In contrast, in unburned forest they spent on average most time on trees with a DBH of 5-15 and 35$45 \mathrm{~cm}$ (Fig 3C).

\section{DISCUSSION}

This study is among the first to quantify the foraging requirements of the Eurasian Three-toed Woodpecker in burned forest and to compare foraging behavior between burned and unburned forests. By determining simultaneously the characteristics of selected foraging substrates and foraging behavior as measured through foraging time, this study provides a comprehensive overview of the foraging ecology of the Eurasian Three-toed Woodpecker in boreal forests. The two methods provided complementary knowledge and thus using them simultaneously helps to improve our understanding of the woodpecker's foraging behavior (Imbeau and Desrochers 2002, Nappi et al. 2015). Knowledge from this study is important for the development of strategies for forest management and ecological restoration based on the relation between tree dynamics and the foraging ecology of woodpeckers.

Based on tree selection analyses, our results demonstrate that in both unburned and burned boreal forest, tree species, decay stage, and $\mathrm{DBH}$ are important factors influencing foraging substrate selection by the Eurasian Three-toed Woodpecker. In addition, patterns of substrate use as measured through foraging time differed substantially between burned and unburned forest. In burned forest, we found less pronounced importance of tree species (especially based on foraging time). Healthy living trees seem to be more important in terms of foraging time than suggested by the analysis of the characteristics of selected substrates that does not account for time. This may be an indication of the importance of tree sap from living trees as a food source for the woodpecker. However, bark scaling was the main foraging technique, which corroborates previous knowledge suggesting that the Three-toed Woodpecker is a specialist closely associated with bark beetles (Curculionidae; Scolytinae) as a main prey (Fayt 1999, Nappi et al. 2015).

\section{Characteristics of selected foraging substrates}

Our results suggest that in burned forest stands, typical foraging substrates for Three-toed Woodpeckers are spruce or birch, recently dead trees (decay stage 3), and trees with a $\mathrm{DBH}$ in the categories $15-25 \mathrm{~cm}$ and $35-45 \mathrm{~cm}$. Our results are in line with those obtained from burned forests of Northern America, where the American Three-toed Woodpecker and Black-backed Woodpecker (Picoides arcticus) have been shown to select larger snags $(>15 \mathrm{~cm})$ for foraging (Murphy and Lehnhausen 1998, Nappi and Drapeau 2011).

In unburned forests, the Three-toed Woodpecker showed a clear preference for Norway spruce. One possible explanation for this is that their main prey, bark beetles, are relatively more abundant in spruce than in the other tree species in unburned forest compared to burned forest. A study preformed in the same study system in 2013 (Hägglund and Hjältén 2018) provides support for this, although it is unclear whether this pattern for bark beetle distribution persisted until this study was performed (2017). Furthermore, Three-toed Woodpeckers preferred dying trees 
(decay stage 2), recently dead trees (decay stage 3 ), and trees dead for a longer time (decay stage 4), as well as trees with a DBH of 15-25 cm. Healthy living trees and trees with a DBH in the category of 5-15 were avoided according to the substrate selection analyses. These results are in line with knowledge pertaining to American Three-toed Woodpeckers in unburned forest (Imbeau and Desrochers 2002, Nappi et al. 2015), which showed a stronger preference for fresh larger diameter snags over living trees. Nappi et al. (2015) found that the main prey item of American Threetoed Woodpecker, i.e., Scolytinae, were found in high abundance in trees selected for foraging.

\section{Foraging behavior as measured through foraging time}

The prediction that time spent on a selected foraging substrate should differ between burned and unburned forest because of changes in substrate properties caused by fire was partly supported. We found such differences in terms of tree species, decay stage, and DBH. In unburned forests, Three-toed Woodpeckers clearly spent most of their foraging time on spruce. This is in line with other studies that reported that Three-toed Woodpeckers primarily forage on spruce (Picea spp.; Hogstad 1991, Villard 1994, Imbeau and Desrochers 2002, Pechacek 2006a, Nappi et al. 2015). Nevertheless, such a clear difference in foraging time between tree species was not found in burned forests. Even though most time was spent on spruce and birch, a considerable amount of time was also spent on pine. This in contrast to other studies that show that two years after wildfire in mixed burned forest stands, Three-toed Woodpeckers mainly forage on spruce trees (Murphy and Lehnhausen 1998, Fayt 1999). The time elapsed since fire and fire severity are two important factors that should be taken into account when comparing studies regarding fire and woodpecker behavior. High abundance of insects is generally limited to the first few years after fire (SaintGermain et al. 2004b, Boulanger and Sirois 2007), which is also found for woodpecker abundance (Murphy and Lehnhausen 1998, Fayt 2003, Gustafsson et al. 2019). However, low fire severity can prolong the availability of appropriate host trees for saproxylic insects and thus enhance food availability over a longer time period (Nappi et al. 2010). An important portion of our burned study stands were characterized by low to moderate fire severity that resulted in mixture of live, declining, and dead trees, which may explain some of the differences with other studies. In addition, one other potential explanation for woodpecker use of both pine and spruce in this study may be that after prescribed burning, saproxylic beetle distribution becomes more homogenized between tree species (Wikars 2002, Nappi et al. 2010, Toivanen and Kotiaho 2010, Hägglund and Hjältén 2018), making woodpeckers more likely to spend time foraging on several different tree species. For example, Nappi et al. (2010), found no significant differences between mean densities of wood-boring Cerambycidae larvae in bole segments of lightly burned pine vs. spruce trees. Still, we did not measure prey availability in this study and can therefore only speculate regarding explanations behind the observed foraging patterns. More studies combining measures on foraging preferences and prey distribution and abundance are therefore needed.

In both burned and unburned forest, Three-toed Woodpeckers on average spent most of their foraging time on recently dead trees (decay stage 3). This is in line with results from earlier studies reporting that Three-toed Woodpeckers prefer fresh snags (Hogstad 1991, Pechacek 2006a, Nappi et al. 2015). However, we found that Three-toed Woodpeckers also spent a considerable amount of time on living trees, in spite of the fact that living trees were avoided in terms of substrate selection. On healthy living trees, the woodpecker spent on average $55 \%$ of their time licking sap. These results may indicate that the woodpeckers dedicate a disproportionally larger amount of time to sap licking, i.e., healthy living trees form a small proportion of the trees used by the woodpecker, but the woodpeckers spend a substantial amount of time on these trees. Hence, sap from living trees may be an important food source for both the Eurasian and American Three-toed Woodpecker (Nappi et al. 2015, Pakkala et al. 2018b). Overall, we found that Three-toed Woodpeckers spent up to $19.9 \%$ of their total foraging time sap-licking in unburned and $14.7 \%$ in burned forest. This is similar to what Nappi et al. (2015) reported in mature coniferous forest by American Three-toed Woodpecker. They demonstrated that they spent up to $20 \%$ of their foraging time in sap-licking on healthy trees. Additionally, for the Eurasian Three-toed Woodpecker it has been shown that up to $33 \%$ of their foraging time was spent sap-licking (Pakkala et al. 2018b). In this study, Three-toed Woodpeckers in burned forest spent the most time foraging on trees with a DBH between $15-25 \mathrm{~cm}$ while in unburned forest they spent on average the most time on trees with a DBH of $5-15$ and $35-45$. These results are partly in line with studies from unburned forest, where it has been shown that Three-toed Woodpeckers mainly forage on trees with a DBH > $10 \mathrm{~cm}$ (Hogstad 1977, 1991, Pechacek and d'OleireOltmanns 2004, Zhu et al. 2012). However, this study suggests that, once selected, woodpeckers may spend considerable time utilizing smaller diameter trees in the range of $5-15 \mathrm{~cm}$ in unburned forest. We have shown that trees in this range were not used for sap licking and thus the most likely explanation is that natural self-thinning in the studied old forest stands leads to the slow death of small-diameter spruce, which are abundantly colonized by bark beetles such as Pityogenes chalcographus (Fayt 1999).

We confirmed that in unburned forest the primary foraging method of Three-toed Woodpeckers is bark-scaling and that their main foraging location is on the trunk (Hogstad 1977, 1991, Pechacek 2006a). Moreover, we found that Three-toed Woodpeckers behaved similarly in burned forests. Average diameter of foraging substrate did not differ between forest types; these results are similar to what was found by Zhu et al. (2012) and Pechacek (2006a) in unburned forests. Our data did support our prediction that foraging height, measured through foraging time, would differ between burned and unburned forest. However, the differences found between sexes were not influenced by treatment, but treatment had, independently of sex, an effect on foraging height. Our results show that Three-toed Woodpeckers in burned forest spent more foraging time on the lower part of the trunk $(0-2 \mathrm{~m})$. With regard to sex, our results are in line with the literature showing that male Three-toed Woodpeckers generally forage lower on the trunk than females (Hogstad 1977, 1991, Pechacek 2006a, Zhu et al. 2012). However, these results may suggest that the spatial distribution of prey species changes after prescribed burning. Prescribed burning usually results in higher fire impact on the lower part of the trees. It is suggested 
that shading, bark thickness, and burn severity are important factors affecting the spatial distribution of bark beetles on trees (Jakuš 1998, Fayt 1999, Foit 2010). Similar to our results, Nappi et al. (2003) and Nappi and Drapeau (2011) found that Blackbacked Woodpeckers in burned forests foraged mainly on the lower part of the tree and related this to high prey availability after fire in the lower five meters of the trunk. Within this study we did not measure food availability but it will be of importance to investigate the consequences of fire on the spatial distribution of prey species. Sampling saproxylic arthropods would be a logical next step to fill this knowledge gap.

\section{CONCLUSIONS}

In this study we found that in both burned and unburned forests, typical foraging substrates can be characterized as freshly dead trees with a DBH of more than $15 \mathrm{~cm}$. Additionally, data on time spent foraging on the different substrates suggest that also substrates in the 5-15 DBH range and living trees are important. Living trees are probably important for sap licking.

This study was performed 5-6 years after fire and still the burned sites offered foraging substrate for Three-toed Woodpeckers. This is in contrast to wildfires, where it has been found that Three-toed Woodpecker densities often drop after 2-4 years (Fayt 2003, Gustafsson et al. 2019). Still, Nappi et al. (2010)'s study of the Black-backed Woodpecker showed a similar pattern in wildfires that burned with variable severity as in our study: the woodpecker still occurred at high densities 6-8 years after wildfire. One possible explanation for this variation is that under low intensity fires (as is usually the case in prescribed burning), mortality of the different trees in the forest can occur more gradually over several years. It can take several years for partially burned trees to die from fire stress or beetle attack (McHugh and Kolb 2003). Therefore, bark beetle abundance may remain elevated across the forest stand a longer time after fire. This suggests that the use of prescribed burning can be an efficient way for rapid and apparently long-lasting enrichment of important forest structures for woodpeckers.

In unburned forests, quantity and quality of dead wood is critical for the occurrence of Three-toed Woodpeckers and other dead wood associated species (Bütler et al. 2004b, Roberge et al. 2008). Even though dead wood quantities in Swedish forests have increased by $25 \%$ since 1994, (Jonsson et al. 2016), the levels are still only about $10 \%$ of those found in old growth forest and heterogeneity of dead wood types is low in terms of tree species, DBH, and decay stages. Additionally, Hedwall and Mikusiński (2015) demonstrated very low levels and slow increase of dead wood in Swedish protected areas. Therefore, we suggest that the best conservation strategy for the Three-toed Woodpecker is to conserve remaining old-growth forests and create more fresh dying trees and dead wood of different tree species and DBH classes in managed and protected forests to continuously provide sufficient quantities of recently dead or dying trees at the landscape level.

Overall, the results from this study support earlier recommendations by Drapeau et al. (2009) that a better understanding of the foraging ecology of woodpeckers and their association to deadwood is necessary for successful conservation work in managed forest landscapes. Rather than solely focusing on snag numbers for nesting and roosting purposes, a broader consideration of decaying and dead trees dynamics relating to the foraging ecology of woodpeckers and relationships between tree decay, insect abundance, and woodpeckers foraging should be considered in forest conservation and management.

Responses to this article can be read online at: http://www.ace-eco.org/issues/responses.php/1477

\section{Acknowledgments:}

We are grateful to Dariusz Graszka-Petrykowski and Félix Lorrain Landry for help with the field work and to the anonymous referees for their constructive comments. We thank Holmen Skog, SCA, and the county boards of Västernorrland and Västerbotten for hosting the experiment and for their valuable help with the selection of study sites. Funding was provided by the foundation Oscar och Lili Lamms Minne, Sweden (grant DO2103-0059) and the Kempe Foundation, Sweden (grant SMK-1339).

\section{LITERATURE CITED}

Ahti, T., L. Härnet-Ahti, and J. Jalas. 1968. Vegetation zones and their sections in northwestern Europe. Annales Botanici Fennici 5:169-211.

Andersson, J., E. Domingo Gómez, S. Michon, and J.-M. Roberge. 2018. Tree cavity densities and characteristics in managed and unmanaged Swedish boreal forest. Scandinavian Journal of Forest Research 33:233-244. https://doi.

org/10.1080/02827581.2017.1360389

Angelstam, P. K. 1998. Maintaining and restoring biodiversity in European boreal forests by developing natural disturbance regimes. Journal of Vegetation Science 9:593-602. https://doi. org/10.2307/3237275

Bergeron, Y., S. Gauthier, M. Flannigan, and V. Kafka. 2004. Fire regimes at the transition between mixedwood and coniferous boreal forest in northwestern Quebec. Ecology 85:1916-1932. https://doi.org/10.1890/02-0716

Boucher, J., E. T. Azeria, J. Ibarzabal, and C. Hébert. 2012. Saproxylic beetles in disturbed boreal forests: temporal dynamics, habitat associations, and community structure. Écoscience 19:328-343. https://doi.org/10.2980/19-4-3503

Boulanger, Y., and L. Sirois. 2007. Postfire succession of saproxylic arthropods, with emphasis on Coleoptera, in the north boreal forest of Quebec. Environmental Entomology 36:128-141. https://doi.org/10.1603/0046-225X-36.1.128

Bütler, R., P. Angelstam, P. Ekelund, and R. Schlaepfer. $2004 b$. Dead wood threshold values for the Three-toed Woodpecker presence in boreal and sub-Alpine forest. Biological Conservation 119:305-318. https://doi.org/10.1016/j.biocon.2003.11.014

Bütler, R., P. Angelstam, and R. Schlaepfer. 2004a. Quantitative snag targets for the Three-toed Woodpecker Picoides tridactylus. Ecological Bulletins 51:219-232. 
Czeszczewik, D., W. Walankiewicz, C. Mitrus, T. Tumiel, T. Stański, M. Sahel, and G. Bednarczyk. 2013. Importance of dead wood resources for woodpeckers in coniferous stands of the Białowieża Forest. Bird Conservation International 23:414-425. https://doi.org/10.1017/S0959270912000354

Desrochers, A. 1992. Age and foraging success in European blackbirds: variation between and with individuals. Animal Behaviour 43:885-894. https://doi.org/10.1016/S0003-3472(06) 80002-3

Drapeau, P., A. Nappi, L. Imbeau, and M. Saint-Germain. 2009. Standing deadwood for keystone bird species in the eastern boreal forest: managing for snag dynamics. Forestry Chronicle 85:227-234. https://doi.org/10.5558/tfc85227-2

Drever, M. C., K. E. H. Aitken, A. R. Norris, and K. Martin. 2008. Woodpeckers as reliable indicators of bird richness, forest health and harvest. Biological Conservation 141:624-634. https:// doi.org/10.1016/j.biocon.2007.12.004

Edworthy, A. B., M. C. Drever, and K. Martin. 2011. Woodpeckers increase in abundance but maintain fecundity in response to an outbreak of mountain pine bark beetles. Forest Ecology and Management 261:203-210. https://doi.org/10.1016/j. foreco.2010.10.006

Esseen, P.-A., B. Ehnström, L. Ericson, and K. Sjöberg. 1997. Boreal forests. Ecological Bulletins 46:16-47.

Fayt, P. 1999. Available insect prey in bark patches selected by the Three-toed Woodpecker Picoides tridactylus prior to reproduction. Ornis Fennica 76:135-140.

Fayt, P. 2003. Insect prey population changes in habitats with declining vs. stable Three-toed Woodpecker Picoides tridactylus populations. Ornis Fennica 80:182-192.

Foit, J. 2010. Distribution of early-arriving saproxylic beetles on standing dead Scots pine trees. Agricultural and Forest Entomology 12:133-141. https://doi.org/10.1111/j.1461-9563.2009.00461. $\mathrm{x}$

Gauthier, S., P. Bernier, T. Kuuluvainen, A. Z. Shvidenko, and D. G. Schepaschenko. 2015. Boreal forest health and global change. Science 349:819-822. https://doi.org/10.1126/science.aaa9092

Gustafsson, L., M. Berglind, A. Granström, A. Grelle, G. Isacsson, P. Kjellander, S. Larsson, M. Lindh, L. B. Pettersson, J. Strengbom, B. Stridh, T. Sävström, G. Thor, L.-O. Wikars, and G. Mikusiński. 2019. Rapid ecological response and intensified knowledge accumulation following a north European mega-fire. Scandinavian Journal of Forest Research 34:234-253. https://doi. org/10.1080/02827581.2019.1603323

Hägglund, R., and J. Hjältén. 2018. Substrate specific restoration promotes saproxylic beetle diversity in boreal forest set-asides. Forest Ecology and Management 425:45-58. https://doi. org/10.1016/j.foreco.2018.05.019

Hedwall, P.-O., and G. Mikusiński. 2015. Structural changes in protected forests in Sweden: implications for conservation functionality. Canadian Journal of Forest Research 45:1215-1224. https://doi.org/10.1139/cjfr-2014-0470
Hekkala, A.-M., M.-L. Päätalo, O. Tarvainen, and A. Tolvanen. 2014. Restoration of young forests in eastern Finland: benefits for saproxylic beetles (Coleoptera). Restoration Ecology 22:151-159. https://doi.org/10.1111/rec.12050

Hjältén, J., M. Dynesius, A.-M. Hekkala, A. Karlsson-Tiselius, T. Löfroth, and R. Mugerwa-Pettersson. 2018. Saproxylic insects and fire. Pages 669-691 in M. D. Ulyshen, editor. Saproxylic insects. Springer-Verlag, Heidelberg, Germany. https://doi. org/10.1007/978-3-319-75937-1_20

Hjältén, J., R. Hägglund, T. Löfroth, J.-M. Roberge, M. Dynesius, and J. Olsson. 2017. Forest restoration by burning and gap cutting of voluntary set-asides yield distinct immediate effects on saproxylic beetles. Biodiversity and Conservation 26:1623-1640. https://doi.org/10.1007/s10531-017-1321-0

Hogstad, O. 1977. Seasonal change in intersexual niche differentiation of the Three-toed woodpecker Picoides tridactylus. Ornis Scandinavica 8:101-111. https://doi.org/10.2307/3676095

Hogstad, O. 1991. The effect of social dominance on foraging by the Three-toed Woodpecker Picoides tridactylus. Ibis 133:271-276. https://doi.org/10.1111/j.1474-919X.1991.tb04569. $\mathrm{x}$

Hoyt, J. S., and S. J. Hannon. 2002. Habitat associations of Blackbacked and Three-toed Woodpeckers in the boreal forest of Alberta. Canadian Journal of Forest Research 32:1881-1888. https://doi.org/10.1139/x02-109

Hunter, M. L. 1993. Natural fire regimes as spatial models for managing boreal forests. Biological Conservation 65:115-120. https://doi.org/10.1016/0006-3207(93)90440-C

Hyvärinen, E., J. Kouki, and P. Martikainen. 2009. Prescribed fires and retention trees help to conserve beetle diversity in managed boreal forests despite their transient negative effects on some beetle groups. Insect Conservation and Diversity 2:93-105. https://doi.org/10.1111/j.1752-4598.2009.00048.x

Imbeau, L., and A. Desrochers. 2002. Foraging ecology and use of drumming trees by Three-toed Woodpeckers. Journal of Wildlife Management 66:222-231. https://doi.org/10.2307/3802888

Jakuš, R. 1998. Patch level variation on bark beetle attack (Col., Scolytidae) on snapped and uprooted trees in Norway spruce primeval natural forest in endemic condition: effects of host and insolation. Journal of Applied Entomology 122:409-421. https:// doi.org/10.1111/j.1439-0418.1998.tb01521.x

Jonsson, B. G., M. Ekström, P.-A. Esseen, A. Grafström, G. Ståhl, and B. Westerlund. 2016. Dead wood availability in managed Swedish forests - policy outcomes and implications for biodiversity. Forest Ecology and Management 376:174-182. https://doi.org/10.1016/j.foreco.2016.06.017

Kajtoch, L., T. Figarski, and J. Pelka. 2013. The role of forest structural elements in determining the occurrence of two specialist woodpecker species in the Carpathians, Poland. Ornis Fennica 90:23-40.

Kärvemo, S., C. Björkman, T. Johansson, J. Weslien, and J. Hjältén. 2017. Forest restoration as a double-edged sword: the conflict between biodiversity conservation and pest control. 
Journal of Applied Ecology 54:1658-1668. https://doi. org/10.1111/1365-2664.12905

Kumar, R., G. Shahabuddin, and A. Kumar. 2014. Habitat determinants of woodpecker abundance and species richness in sub-Himalayan dipterocarp forests of north-west India. Acta Ornithologica 49:243-256. https://doi.org/10.3161/173484714X687136

Kuuluvainen, T. 2002. Disturbance dynamics in boreal forests: defining the ecological basis of restoration and management of biodiversity. Silva Fennica 36(1):547. https://doi.org/10.14214/ sf. 547

Lammertink, M. 2014. Trends in threat status and priorities in conservation of the woodpeckers of the world. Acta Ornithologica 49:207-219. https://doi.org/10.3161/173484714X687109

Lehtonen, I., A. Venäläinen, M. Kämäräinen, H. Peltola, and H. Gregow. 2016. Risk of large-scale fires in boreal forests of Finland under changing climate. Natural Hazards and Earth System Sciences 16:239-253. https://doi.org/10.5194/nhess-16-239-2016

Linder, P., and L. Östlund. 1998. Structural changes in three midboreal Swedish forest landscapes, 1885-1996. Biological Conservation 85:9-19. https://doi.org/10.1016/S0006-3207(97) 00168-7

Lowe, J., D. Pothier, G. Rompré, and J.-P. L. Savard. 2012. Longterm changes in bird community in the unmanaged post-fire eastern Québec boreal forest. Journal of Ornithology 153:1113-1125. https://doi.org/10.1007/s10336-012-0841-3

Machlis, L., P. W. D. Dodd, and J. C. Fentress. 1985. The pooling fallacy: problems arising when individuals contribute more than one observation to the data set. Zeitschrift für Tierpsychologie 68:201-214. https://doi.org/10.1111/j.1439-0310.1985.tb00124.X

Manly, B. F. J., L. L. McDonald, D. L. Thomas, T. L. McDonald, and W. P. Erickson. 2002. Resource selection by animals: statistical design and analysis for field studies. Kluwer Academic, Norwell, Massachusetts, USA.

Martin, P., and P. Bateson. 1993. Measuring behavior: an introductory guide. Second edition. Cambridge University Press, Cambridge, UK.

McHugh, C. W., and T. E. Kolb. 2003. Ponderosa pine mortality following fire in northern Arizona. International Journal of Wildland Fire 12:7-22. https://doi.org/10.1071/WF02054

Mikusiński, G. 2006. Woodpeckers: distribution, conservation, and research in a global perspective. Annales Zoologici Fennici 43:86-95.

Mikusiński, G., M. Gromadzki, and P. Chylarecki. 2001. Woodpeckers as indicators of forest bird diversity. Conservation Biology 15:208-217.

Murphy, E. C., and W. A. Lehnhausen. 1998. Density and foraging ecology of woodpeckers following a stand-replacement fire. Journal of Wildlife Management 62:1359-1372. https://doi. org/10.2307/3802002

Nappi, A., and P. Drapeau. 2009. Reproductive success of the Black-backed Woodpecker (Picoides arcticus) in burned boreal forests: are burns source habitats? Biological Conservation 142:1381-1391. https://doi.org/10.1016/j.biocon.2009.01.022
Nappi, A., and P. Drapeau. 2011. Pre-fire forest conditions and fire severity as determinants of the quality of burned forests for deadwood-dependent species: the case of the Black-backed Woodpecker. Canadian Journal of Forest Research 41:994-1003. https://doi.org/10.1139/x11-028

Nappi, A., P. Drapeau, J.-F. Giroux, and J.-P. L. Savard. 2003. Snag use by foraging Black-backed Woodpecker (Picoides arcticus) in a recently burned eastern boreal forest. Auk 120:505-511. https://doi.org/10.1093/auk/120.2.505

Nappi, A., P. Drapeau, and A. Leduc. 2015. How important is dead wood for woodpeckers foraging in eastern North American boreal forests? Forest Ecology and Management 346:10-21. https:// doi.org/10.1016/j.foreco.2015.02.028

Nappi, A., P. Drapeau, M. Saint-Germain, and V. A. Angers. 2010. Effect of fire severity on long-term occupancy of burned boreal conifer forests by saproxylic insects and wood-foraging birds. International Journal of Wildland Fire 19:500-511. https:// doi.org/10.1071/WF08109

Ojeda, V., and L. Chazarreta. 2014. Home range and habitat use by Magellanic Woodpeckers in an old-growth forest of Patagonia. Canadian Journal of Forest Research 44:1265-1273. https://doi. org/10.1139/cjfr-2013-0534

Östlund, L., O. Zackrisson, and A. L. Axelsson. 1997. The history and transformation of a Scandinavian boreal forest landscape since the 19th century. Canadian Journal of Forest Research 27:1198-1206. https://doi.org/10.1139/x97-070

Pakkala, T., I. Hanski, and E. Tomppo. 2002. Spatial ecology of the Three-toed Woodpecker in managed forest landscapes. Silva Fennica 36(1):563. https://doi.org/10.14214/sf.563

Pakkala, T., J. Piiroinen, J. Lakka, J. Tiainen, M. Piha, and J. Kouki. 2018b. Tree sap as an important seasonal food resource for woodpeckers: the case of the Eurasian Three-toed Woodpecker (Picoides tridactylus) in southern Finland. Annales Zoologici Fennici 55:79-92. https://doi.org/10.5735/086.055.0108

Pakkala, T., J. Tiainen, M. Piha, and J. Kouki. 2018a. Three-toed Woodpecker cavities in trees: a keystone structural feature in forests shows decadal persistence but only short-term benefit for secondary cavity-breeders. Forest Ecology and Management 413:70-75. https://doi.org/10.1016/j.foreco.2018.01.043

Pechacek, P. 2004. Spacing behaviour of Eurasian Three-toed Woodpecker (Picoides tridactylus) during the breeding season in Germany. Auk 121:58-67. https://doi.org/10.1642/0004-8038 (2004)121[0058:SBOETW]2.0.CO;2

Pechacek, P. 2006a. Foraging behaviour of Eurasian Three-toed Woodpeckers (Picoides tridactylus alpinus) in relation to sex and season in Germany. Auk 123:235-246. https://doi.org/10.1093/ auk/123.1.235

Pechacek, P. 2006b. Breeding performance, natal dispersal, and nest site fidelity of the Three-toed Woodpecker in the German Alps. Annales Zoologici Fennici 43:165-176.

Pechacek, P., and W. d'Oleire-Oltmanns. 2004. Habitat use of the Three-toed Woodpecker in central Europe during the breeding period. Biological Conservation 116:333-341. https://doi. org/10.1016/S0006-3207(03)00203-9 
Roberge, J.-M., and P. Angelstam. 2006. Indicator species among resident forest birds - a cross-regional evaluation in northern Europe. Biological Conservation 130:134-147. https://doi. org/10.1016/j.biocon.2005.12.008

Roberge, J.-M., P. Angelstam, and M.-A. Villard. 2008. Specialised woodpeckers and naturalness in hemiboreal forests deriving quantitative targets for conservation planning. Biological Conservation 141:997-1012. https://doi.org/10.1016/j.biocon.2008.01.010

Rolstad, J., Y.-L. Blanck, and K. O. Storaunet. 2017. Fire history in a western Fennoscandian boreal forest as influenced by human land use and climate. Ecological Monographs 87:219-245. https:// doi.org/10.1002/ecm.1244

Saint-Germain, M., P. Drapeau, and C. M. Buddle. 2008. Persistence of pyrophilous insects in fire-driven boreal forests: population dynamics in burned and unburned habitats. Diversity and Distributions 14:713-720. https://doi.org/10.1111/ j.1472-4642.2007.00452.x

Saint-Germain, M., P. Drapeau, and C. Hébert. 2004a. Comparison of Coleoptera assemblages from a recently burned and unburned black spruce forests of northeastern North America. Biological Conservation 118:583-592. https://doi. org/10.1016/j.biocon.2003.10.007

Saint-Germain, M., P. Drapeau, and C. Hébert. $2004 b$. Xylophagous insect species composition and patterns of substratum use on fire-killed black spruce in central Quebec. Canadian Journal of Forest Research 34:677-685. https://doi. org/10.1139/x03-235

Stachura-Skierczyńska, K., T. Tumiel, and M. Skierczyński. 2009. Habitat prediction model for Three-toed Woodpecker and its implications for the conservation of biologically valuable forests. Forest Ecology and Management 258:697-703. https://doi. org/10.1016/j.foreco.2009.05.007

Stokland, J., J. Siitonen, and B. G. Jonsson. 2012. Biodiversity in dead wood. Cambridge University Press, Cambridge, UK. https:// doi.org/10.1017/CBO9781139025843

Therneau, T., and T. Lumley. 2009. Survival: survival analysis, including penalized likelihood. R Package Version 2.42-3. [online] URL: http://CRAN.R-project.org/package=survival

Thomas, J. W., R. G. Anderson, C. Maser, and L. Bull. 1979. Snags. Chapter 5 in J. W. Thomas, editor. Wildlife habitat in managed forest the Blue Mountain of Oregon and Washington. U. S. Forest Service, Wildlife Management Institute, U.S. Dept. of Interior, Bureau of Land Management, Washington, D.C., USA.

Toivanen, T., and J. S. Kotiaho. 2010. The preferences of saproxylic beetle species for different dead wood types created in forest restoration treatments. Canadian Journal of Forest Research 40:445-464. https://doi.org/10.1139/X09-205
Tremblay, J. A., J. Ibarzabal, C. Dussault, and J.-P. L. Savard. 2009. Habitat requirements of breeding Black-backed Woodpeckers (Picoides arcticus) in managed, unburned boreal forest. Avian Conservation and Ecology 4(1):2. https://doi. org/10.5751/ACE-00297-040102

Vergara-Tabares, D. L., M. Lammertink, E. G. Verga, A. A. Schaaf, and J. Nori. 2018. Gone with the forest: assessing global woodpecker conservation from land use patterns. Diversity and Distributions 24:640-651. https://doi.org/10.1111/ddi.12710

Versluijs, M., S. Eggers, J. Hjältén, T. Löfroth, and J.-M. Roberge. 2017. Ecological restoration in boreal forest modifies the structure of bird assemblages. Forest Ecology and Management 401:75-88. https://doi.org/10.1016/j.foreco.2017.06.055

Versluijs, M., J. Hjältén, and J.-M. Roberge. 2019. Ecological restoration modifies the value of biodiversity indicators in resident boreal forest birds. Ecological Indicators 98:104-111. https://doi.org/10.1016/j.ecolind.2018.10.020

Villard, P. 1994. Foraging behavior of Black-backed and Threetoed Woodpeckers during spring and summer in a Canadian boreal forest. Canadian Journal of Zoology 72:1957-1959. https:// doi.org/10.1139/z94-266

Wallenius, T. 2011. Major decline in fires in coniferous forests reconstructing the phenomenon and seeking for the cause. Silva Fennica 45(1):36. https://doi.org/10.14214/sf.36

Walters, J. R., S. J. Daniels, J. H. Carter, and P. D. Doerr. 2002. Defining quality of Red-cockaded Woodpecker foraging habitat based on habitat use and fitness. Journal of Wildlife Management 66:1064-1082. https://doi.org/10.2307/3802938

Wesołowski, T., D. Czeszczewik, and P. Rowiński. 2005. Effects of forest management on Three-toed Woodpecker Picoides tridactylus distribution in the Białowieża Forest (NE Poland): conservation implications. Acta Ornithologica 40:53-60. https:// doi.org/10.3161/068.040.0111

Wikars, L.-O. 2002. Dependence on fire in wood-living insects: an experiment with burned and unburned spruce and birch logs. Journal of Insect Conservation 6:1-12. https://doi.org/10.1023/ A:1015734630309

Zhu, Y., N. Lü, P. Pechacek, J. Li, and Y.-H. Sun. 2012. Foraging behavior of the Eurasian Three-toed Woodpecker subspecies Picoides tridactylus funebris in southern Gansu, China. Chinese Birds 3:60-66. https://doi.org/10.5122/cbirds.2012.0002
Editor-in-Chief: Keith A.Hobson Subject Editor: Fiona KASchmiegelow
Sponsored by the Society of Canadian Ornithologists and Birds Canada

Parrainée par la Société des ornithologistes du Canada et Oiseaux Canada

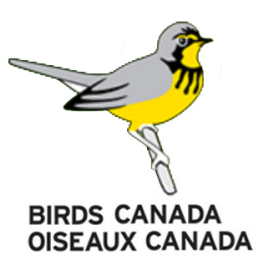

